\title{
Property-Liability Insurers Recapitalization: An Event Study
}

Yuan Yuan, University of Wisconsin - Whitewater, USA

\begin{abstract}
This paper utilizes an event study methodology and presents an empirical investigation of property-liability $(P \& L)$ insurers' recapitalization behavior after the industry-wide capital shock, September 11 attacks. The Probit regression results provide the evidence that external capital markets are more likely to be accessed by property-liability insurers which are larger in size, have greater need to replenish capital stocks, have greater growth opportunities, higher cash flow volatilities, greater coverage, or those who already used financial debt. Poor financial quality insurers appear to be constrained.
\end{abstract}

Keywords: Property-Liability Insurer; Securities Offerings; Recapitalization; September 11 Attacks

\section{INTRODUCTION}

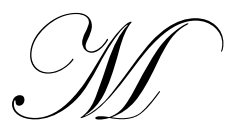

odigliani-Miller irrelevance theorems suggest that companies can, at any time, costlessly access capital markets at fair value in the perfect capital markets, the firm value won't be affected by its capital structure and allocations, and there would be no incentive for firms to manage or hedge risks (Modigliani and Miller, 1958). However, Modigliani-Miller irrelevance theorems fail in our real world due to a variety of distortionary forces that prevent things from working that well and, therefore, we see that capital structure does matter. Myers and Majluf (1984) showed that external capital is more costly than internal capital. In presence of capital shock or investment and growth opportunities, firms re-capitalize to realize optimal capital structure and maximize firm value.

The U.S. property-liability insurance market has been experiencing capital shortage since the late 2000 and the situation was more severe after the sudden industry-wide capital shock, the terrorist attacks on the World Trade Center (WTC) on September 11 $1^{\text {th }}$, 2001. September 11 attacks have costliest manmade losses in history and the U.S. insurance industry experienced its first net loss year in 2001. September 11 attacks caused massive property loss, business interruption, workers compensation and potential open-ended liability losses. The U.S. property-liability insurance capital funds declined by $\$ 27$ billion in 2001 only (Swiss Re, Sigma, No. 4, 2002). Insurance companies' capacity to write business is constrained because of the shortage of capital stocks. September 11 attacks created the challenge of meeting the largest claims and at the same time created potential investment and growth opportunities for every player in the property-liability insurance industry, especially the commercial lines.

As the insurance industry gears up to replace a good portion of the capital lost in the September 11 attacks, insurers are also seeking to place themselves in a position to profit from the expected surge in demand and resulting increases in premiums and profitability. As predicted by the theory of capacity constraint, there exists a systematic relationship between capital capacity and profitability. The catastrophic losses of 2001, coupled with the fall in capacity, accelerated the price increases in the insurance market, which could lead to improved underwriting margins and higher profitability. Rate increases being realized on various primary lines were published earlier in 2002 by Council of Insurance Agents and Brokers. Commercial-insurance lines have experienced a most upward movement in prices after September 11 attacks, e.g., rate of commercial property insurance increased by $30 \%$, rate of general liability insurance increased by $40 \%$, rate of aviation insurance increased up to $100 \%$. Furthermore, the demand on property-liability insurance also increased dramatically along with soaring prices because of increased risk aversion on people's behaviors and attitudes. 
To increase business capacity and prepare for the anticipated surge in demand, some property-liability insurers announced their financing and recapitalization initiatives right after the September 11 attacks. For example, on September 19, RenaissanceRe Holdings Ltd. stated that it would increase the capital of its primary commercial property insurance unit, Glencoe Insurance Ltd, by $\$ 100$ million; On September 28, MMC Capital announced that to respond to the capacity shortage it was establishing a new specialty insurance and reinsurance subsidiary, AXIS Specialty Ltd., with an initial capitalization of $\$ 1$ billion; On Oct. 24, ACE Ltd. announced its intent to raise additional $\$ 1$ billion in capital and on the same day Arch Capital Group Ltd. stated to establish a new Bermudabased reinsurance subsidiary, Arch Reinsurance; On Oct. 26, PartnerRe planned to raise $\$ 350$ million new capital to provide additional capacity; On Oct. 29, XL Capital Ltd. announced plans to offer up to $\$ 7$ million ordinary shares.

If all firms have equal access to capital markets, firms' responses to changes in the cost of capital differ only because of differences in investment demand. While facing the investment opportunities and potential booming market, not all the U.S. property-liability insurers raised new capital from the external financial market after the industry-wide capital shock event. What we have observed is that, within one year after September 11 attacks, only 73 securities issuings (public/private) in U.S. capital market by property-liability insurers. Therefore, the September 11 attacks provide us a nice library to investigate the re-capitalization behavior of property-liability insurers in presence of capital shocks and potential investment and growth opportunities.

The research questions we address in this study are: who is accessing external capital? And what affect the re-capitalization behavior by property-liability insurers after catastrophic capital shocks? Theoretically, to write more business and catch the new business opportunities, additional capital is necessarily required to support the new business. However, what we have seen is that the property-liability insurers response in different ways. Not all recapitalized by accessing external financial market and some of them relied on their internal capital only. We analyze the characteristics of property-liability insurers when refinancing and explain their re-capitalization behavior after September 11 attacks.

The remainder of the paper is organized as follows: Next section discusses the event methodology and hypothesis. The data and the empirical results are presented in following two sections. The last section concludes the study.

\section{MODEL AND HYPOTHESIS}

We use the event methodology to investigate the property-liability issuers' recapitalization behavior. The following empirical Probit models are set up. The binary dependent variable proxies firm's financing behavior, as $C A P_{i, t}$ equals to 1 if insurer $i$ issued new securities at year $t$, and equal to 0 if otherwise. $C A P_{i, t}=1$ shows that insurer replenishes capital stocks from both internal and external capital market, and $C A P_{i, t}=0$ means that the insurer only relies on its internal capital resources.

Probit model:

$$
Z_{i, t}=\alpha+\beta^{\prime} X+\varepsilon_{i, t}
$$

where $C A P_{i, t}=1$ if $Z_{i, t}>0$; else $C A P_{i, t}=0$, and

$C A P_{i, t}=1$ if firm $i$ accesses external capital in year $t$.

$$
\begin{aligned}
& C A P_{i, t}=\alpha+\beta_{1}\left(\operatorname{RELWTC}_{i, t}\right)+\beta_{2}\left(C F_{i, t}\right)+\beta_{3}\left(C F V_{i, t}\right)+\beta_{4}\left(Q_{i, t}\right)+\beta_{5}\left(\operatorname{COSIZE}_{i, t}\right) \\
& +\beta_{6}\left(\operatorname{LEVERAGE}_{i, t}\right)+\beta_{7}\left(\text { FinDebt }_{i, t}\right)+\beta_{8}\left(Y E A R_{i, t}\right)+\varepsilon_{i, t}
\end{aligned}
$$

where $\quad R E L W T C=$ World Trade Center Losses;

$$
\begin{aligned}
& C F=\text { Cash Flow; } \\
& C F V=\text { Cash Flow Volatility; } \\
& Q=\text { Tobin's Q; }
\end{aligned}
$$




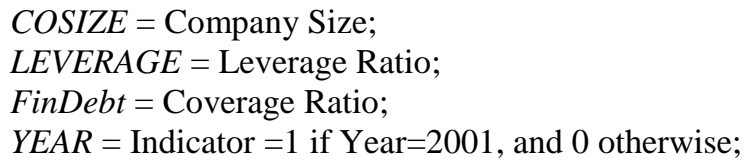

Relative WTC Losses (RELWTC). September 11 attacks led to a loss estimated at $\$ 40-\$ 70$ billion for which little premium was collected. Although $60 \%$ of the losses are borne by international reinsurers, domestic insurers still are exposed to significant losses. Terrorism risk was believed uninsurable after the event because of the high uncertainty of loss frequency and severity. September 11 attacks caused unanticipated extreme capital shocks to the U.S. property-liability insurance companies. We hypothesis that insurers with higher WTC Losses are exposed to higher insolvency risk and therefore are more likely to replenish its capital lag using external capital in the short run. We consider such effects by incorporating each insurer's WTC Losses relative to its previous year equity $(R E L W T C)$, and a positive relationship is expected.

Internal Capital Resource - Cash Flow $(C F)$. Large volume literatures argue that when access to external debt and equity is costly (e.g. compensation for the dealer placing the issue, registration fee, legal and accounting fee), internally available funds provide a cheaper source of financing. Such cost premiums for external finance are generally explained by appealing to models with agency problems and asymmetric information issues. Because of the cost differentials, the higher internal capital level generally provides a cushion for insurers in case of capital shocks. We use the operating cash flow scaled by shareholder's equity as proxy for availability of internal capital, which is defined as income before extraordinary items plus the sum of non-cash charges against income then divided by shareholder's equity. We expect a negative relationship between cash flow and external financing.

Cash Flow Volatility (CFV). Minton and Schrand (1999) documented the impact of cash flow volatility on investment and financing. They showed that higher cash flow volatility was associated with underinvestment in capital expenditures and increased the costs to access capital markets for industrial firms. Here we test their hypothesis in the U.S. property-liability insurance market. Following their measurement, cash flow volatility is defined as the coefficient of variation in a firm's quarterly operating cash flow over the six-years period before September 11, 2001.

Investment and Growth Opportunities - Tobin's $\mathrm{Q}(Q)$. We then test for the opportunistic behavior hypothesis by controlling for potential business opportunities and company growth. Fazzari, Hubbard and Petersen (1988) investigated whether changes in net worth affected investments after controlling for investment opportunities. Their measure of investment opportunities was the expectation by the firm of present value of future profits from additional capital investment. In the neoclassical model of the choice of the capital stocks, this expectation is captured by the marginal q. Therefore, any correlation between changes in net worth and investment given $Q$, violates the frictionless model. As usually used by the literature, Tobin's $Q$ works as proxy of marginal q in our model (e.g., Fazzari, Hubbard and Petersen, 1988; Hoshi, Kashyap, and Scharfstein, 1991). It's calculated as the sum of market value of common stock and book value of preferred stock divided by book value of common stock. If the hypothesis of opportunistic behavior is true, we'll see insurers with more business opportunities are more likely to raise external capital.

Coverage and Asymmetry Information - Company Size (COSIZE). Controlling for the skewness resulting from distinguishable operating scale, company size is measured by logarithms of total assets. Larger companies have greater coverage for capital shock and other adverse effects. Because of their reputation, it is easier for large firms to get external capital than relatively small firms. Asymmetry information is an important issue in the imperfect world. Insiders generally have significantly better information than outsiders about most aspects of the firm's operation and investment. Informational asymmetries can lead to adverse selection, moral hazard, or both. Myers and Majluf (1984) analyzed the case in which the firm's management has information about project returns that is unavailable to investors. Following the corporate finance literature, company size is used as a proxy for the information asymmetry (e.g., Carpenter, Fazzari and Petersen, 1994; and Chevalier and Scharfstein, 1995). Small firms face higher transaction costs for external finance, rarely have bond or commercial paper ratings, and may have greater information problems in capital market. Atiase (1985), Brennan and Hughes (1991), and Collins et al. (1987) suggested that large firms have less information asymmetry than small firms. Ritter (1987) found that large firms have lower costs of issuing securities. So a positive coefficient is expected. 
Financial Constraint and Capital Structure - Leverage Ratio (LEVERAGE). The role of the presence of financial constraint on firm's financing has been addressed in previous researches. To study differences in financing and investment in groups of property-liability insurance companies, constraint and unconstraint insurers should be identified for the potential difference of external financing and accessibility of financial market. Fazzari, Hubbard, and Petersen (1988) and Carpenter, Fazzari, and Petersen (1998) showed the empirical evidence of the negative effects of financial constraint on industrial firms' investment financing. In our model we include leverage ratio to control for the impact of financial constraint. For insurance companies, higher leverage ratio usually results to poor financial standing and lower financial rating. Therefore we expect negative coefficient of leverage ratio because of the low financial quality.

As neoclassical theory predicted, the firm's intertemporal optimization problem could be solved without reference to financial factors. Firms were assumed to face a cost of capital, set in centralized securities markets, which did not depend on the firm's particular financial structure. In our study, we use the firm's financial leverage ratio to test the success of the neoclassical theory of investment: whether firm's financial structure is a factor affecting its financing behavior after September 11 attacks. Any correlation between financial leverage ratio and security offering will violate the neoclassical theory.

Financial Constraint - Coverage Ratio (FinDebt). Coverage ratio is defined as interest expense divided by the sum of the interest expense and net income. The reason for including coverage ratio is because it could be easier and cheaper for firms, who already used financial debt before, to access external capital. More available information exists in the capital market and therefore less information asymmetry and agency costs.

Year Dummy Variable (YEAR). Year dummy variable is included to control for exogenous macroeconomic situation. Year dummy is set equal to 1 if Year $=2001$, and equal to 0 if otherwise.

\section{DATA}

The primary data source used in this study includes Compustat Annual and Quarter dataset, CRSP daily stock dataset, S\&P Bond Guide, and insurance companies's annual financial report. Among the 95 public traded property-liability insurance companies listed in CRSP, 84 have credible data in Compustat. Then 4 were dropped because of missing variables. This left us 80 property-liability insurers listed in U.S. stock market. From Morgan Stanley research report, Insurance - Property \& Casualty (September 13, 2002), we get the list of security offerings by property-liability insurers within one year after September 11, 2001. The list includes 73 new security issues with offering amount ranging from $\$ 1,730$ million to $\$ 17$ million. In total, the new capital financed amounts to $\$ 32$ billion during our study period from 2001 through 2002. Calendar-year data are used and there are 157 observations in our data sample. In Appendix we list the details on variable calculation and data source.

Table 1. Variable Descriptive Statistics $(n=157)$

\begin{tabular}{lcccc}
\hline Variable Description & Mean & Std. Dev. & Min & Max \\
\hline Indicator =1 if issuing securities & 0.197 & 0.399 & 0.000 & 1.000 \\
WTC losses relative to equity (t-1) \% & 0.026 & 0.049 & 0.000 & 0.229 \\
Cash Flow relative to equity \% & 0.031 & 0.417 & -4.671 & 0.752 \\
Cash Flow Volatility & 1.613 & 2.354 & 0.129 & 14.986 \\
Tobin's Q & 1.657 & 1.653 & 0.244 & 13.590 \\
Company Size, $\log$ (Asset) & 3.359 & 0.843 & 1.120 & 5.693 \\
Leverage Ratio, Total Liability / Total Asset & 0.707 & 0.165 & 0.124 & 0.950 \\
Coverage Ratio, (Int. Exp) /( Income+Int. Exp.) & 0.186 & 0.652 & -2.668 & 4.785 \\
Indicator =1 if Year=2001 & 0.503 & 0.502 & 0.000 & 1.000 \\
\hline
\end{tabular}




\section{EMPIRICAL RESULT}

The results of the Probit regression are reported in Table 2. As anticipated, WTC losses have negative and statistically significant coefficient, showing that the September 11 capital shocks were so severe that insurers with huge losses have to access external financial market to replenish the capital stocks in short time. So, propertyliability insurers suffered more from the September 11 attacks are more likely to resort to external capital market.

Consistent with theories, the operating cash flow has negative effect on firm's financing decision. Insurers with higher internal capital level (cash flow) rely on internal capital resource, a cheaper substitute of external capital, more than those with lower availability of internal capital. To check the robustness, we also use net income as proxy for internal capital level, and we get consistent result.

Contrary to Minton and Schrand (1999), who showed that higher cash flow volatility was associated with underinvestment in capital expenditures and increased the costs to access capital markets for industrial firms, our result shows that higher cash flow volatility increases the insurers' possibility of accessing external capital after September 11 attacks. The reason for such contradiction could be that higher cash flow volatility could make internal capital less reliable and relying on high volatile internal capital will not decrease the insolvency risk after September 11 attacks. Although the higher cost of capital, the pressure of remaining financial strength pushes the insurers to resort to external capital market first.

The potential investment and growth opportunity also affects insurers' financing decision after September 11 attacks, and this result supports the hypothesis of opportunistic behavior. Tobin's Q has positive and significant coefficient in the Probit regression result. U.S. property-liability insurers with more growth opportunities are more likely to raise external capital. Consistent with theory that large firms have greater coverage and less information asymmetry, therefore lower costs of accessing capital market, company size has positive and statistically significant coefficient, showing that larger firms are more likely to obtain external capital.

As neoclassical theory predicted, the firm's investment and financing behavior should be independent of the firm's financial structure in the perfect world. The firm's intertemporal optimization problem could be solved without reference to financial factors. While our empirical study presents some evidence of invalidity of the neoclassical theory of investment in the case of September 11 attacks. Leverage ratio significantly affects firm's capital adjustment after September 11. And the negative and significant sign support our hypothesis that insurers with higher leverage ratio have lower financial quality and therefore are constrained on their security offerings. Coverage ratio is positively and significantly related to insurer's security offerings after September 11 attacks. The regression result shows insurers, who already use financial debt, are more likely to access the external finance.

To check the robustness of the Probit regression, we also run a Tobit regression with security offering size relative to issuers' previous year shareholders equity as dependent variable. As expected, we get consistent results.

Table 2. Probit Regression Results of P\&L Insurers Security Offerings (n=157)

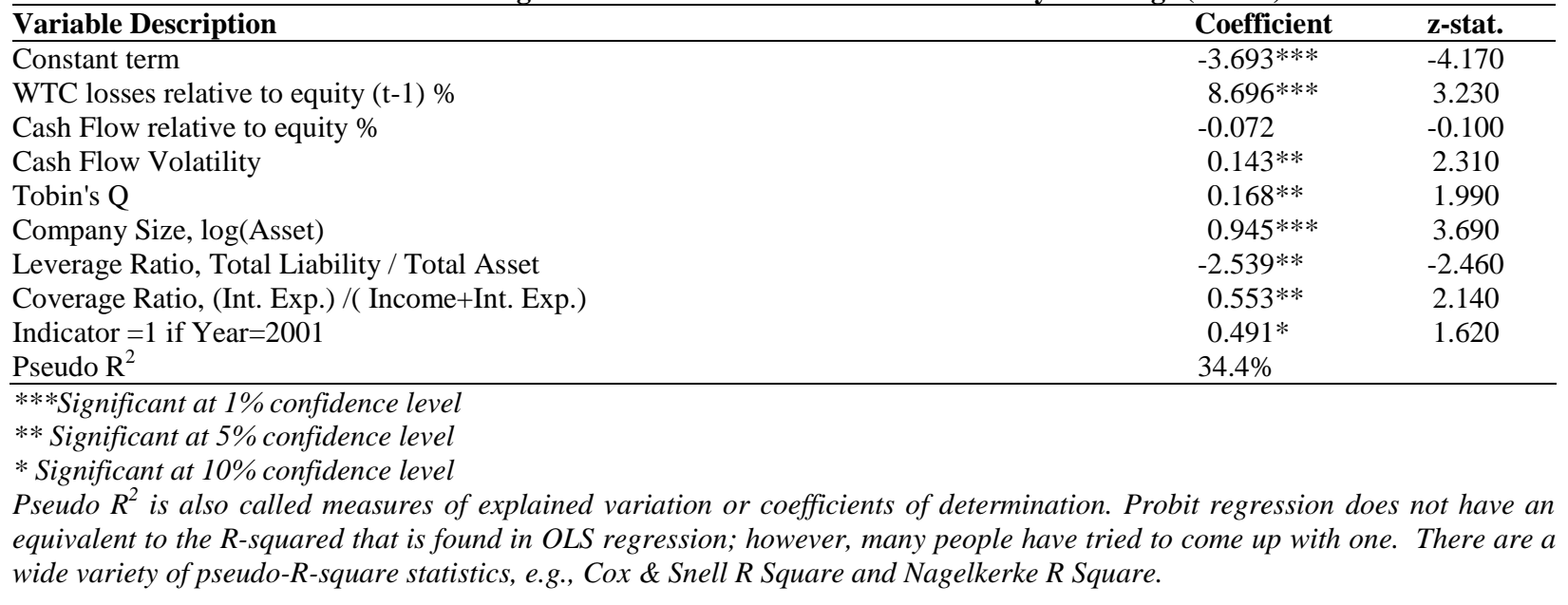




\section{SUMMARY AND CONCLUSION}

This paper presents an empirical event study of property-liability insurers' re-capitalization behavior after September 11 attacks. According to the theory of capacity constraint, there exists a systematic relationship between capital capacity and profitability. The capacity constraint model suggests that unanticipated capital shock will cause higher profitability resulting from increased prices in the short run. With estimation of insured losses ranging from $\$ 40-\$ 70$ billion, September 11 terrorist attacks not only have costliest manmade losses in history but trigger the price soaring in both the life and non-life insurance market. Commercial-insurance lines have experienced a most upward movement in rates.

The demand on $\mathrm{P} \& \mathrm{~L}$ insurance also increased a lot along with soaring prices because of increased risk aversion on people's behaviors or attitudes. After sudden catastrophe losses, the demand on property-liability insurance will increase dramatically, which has been observed after Hurricane Andrew and Northridge earthquake and is true after the September 11 attack. To write more policies, additional capital is necessarily required because insurance companies typically are restricted by regulators to certain capital-related financial ratios, such as premium written to capital.

If all property-liability insurers have equal access to capital markets, their responses to changes in the cost of capital differ only because of differences in investment demand. While facing the optimistic business opportunities and potentially booming market, not all the U.S. property-liability insurers raised new capital from the external financial market. This study investigates the property-liability insurers' re-capitalization behavior after September 11 attacks. Our results provide the evidence that external capital markets are more likely to be accessed by insurers which are large in size, have greater investment and growth opportunities, have higher cash flow volatility, greater coverage, or have greater need to replenish capital stocks.

\section{AUTHOR INFORMATION}

Dr. Yuan Yuan is an assistant professor of insurance and finance at University of Wisconsin, Whitewater. She can be contacted at College of Business and Economics, University of Wisconsin - Whitewater, 800 West Main Street, Whitewater, Wisconsin, US. E-mail: yuany@uww.edu

\section{REFERENCES}

1. Atiase, R. (1985), "Predisclosure Information, Firm Capitalization, and Security Price Behavior Around Earnings Announcements", Journal of Accounting Research, 23: 21-36.

2. Brennan, M., and Hughes, P. (1991), "Stock Prices and the Supply of Information", Journal of Finance, 46: 1665-1691.

3. Carpenter, Robert E., Fazzari, Steven M. and Petersen, Bruce C. (1994), "Inventory Investment, InternalFinance Fluctuations, and the Business Cycle", Brookings Papers on Economic Activity, 2: 75-138.

4. Chevalier, Judith A., and Scharfstein, David S. (1995), "Liquidity Constraints and the Cyclical Behavior of Markups", American Economic Review, 85: 390-396.

5. Collins, D., Kothari, S.P., and Rayburn, J. (1987), "Firm Size and the Information Content of Prices with Respect to Earnings", Journal of Accounting and Economics, 9: 111-138.

6. Fazzari, Steven, Hubbard, R. Glenn and Petersen, B. (1988), "Financing Constraints and Corporate Investment", Brookings Papers on Economic Activity, 141-195.

7. Fazzari, Steven, Hubbard, R. Glenn and Petersen, B. (2000), "Investment-Cash Flow Sensitivities are useful: A Comment on Kaplan and Zingales", The Quarterly Journal of Economics, 695-705.

8. Gron, A. and Lucas, D. (1998), External Financing and Insurance Cycles, in David F. Bradfourd, ed. The Economics of Property-Casualty Insurance, Chicago: The University of Chicago Press.

9. Hoshi, Takeo, Kashyap, Anil and Scharfstein, David (1991), "Corporate Structure, Liquidity, and Investment: Evidence from Japanese Industrial Groups", Quarterly Journal of Economics, 56: 33-60.

10. Minton, Bernadette A., and Schrand, Gatherine (1999), "The Impact of Cash Flow Volatility on Discretionary Investment and The Costs of Debt and Equity Financing", Journal of Financial Economics, 54: 423-460. 
11. Modigliani, F., and Miller, M. (1958), "The Cost of Capital, Corporation Finance, and the Theory of Investment", American Economic Review, 48: 261-297.

12. Myers, Stewart C. and Majluf, Nicholas S. (1984), "Corporate Financing and Investment Decisions When Firms Have Information That Investors Do Not Have", Journal of Financial Economics, 13: 187-221.

13. Ritter, J. (1987), "The Cost of Going Public", Journal of Financial Economics, 19: 269-281

14. Swiss Re, No. 4, (2002), Global Non-life Insurance in a Time of Capacity Shortage. 


\section{APPENDIX: VARIABLE CALCULATION AND DATA SOURCE}

\begin{tabular}{|c|c|c|}
\hline Variable & Description & $\begin{array}{l}\text { Calculation } \\
\text { (The num. below represents the data } \\
\text { item in Compustat Dataset.) }\end{array}$ \\
\hline CAP & $\begin{array}{l}Y=1 \text { if insurers issued equity or debt; } \\
Y=0 \text { otherwise }\end{array}$ & $\begin{array}{l}\text { Morgan Stanley report September } \\
2002\end{array}$ \\
\hline \multirow{2}{*}{ RELWTC } & WTClosses & WTClosses \\
\hline & ShareholderEquity $_{t-1}$ & $216_{t-1}$ \\
\hline \multirow{2}{*}{$\mathrm{CF}$} & IncomeAfterInterest \& Tax + Depreciation \& Amortization & $18+14$ \\
\hline & SharehoderEquity & 216 \\
\hline \multirow{3}{*}{$\mathrm{CFV}$} & $C F V=\frac{\text { Std } \cdot \text { Dev } \cdot(\text { CashFlow })}{2}$ & \\
\hline & Mean $($ CashFlow $)$ & \\
\hline & $\begin{array}{l}\text { CF Volatility is defined as the Coefficient of Variation in a firm's quarterly } \\
\text { operating cash flow over the six-year period preceding the sample year. }\end{array}$ & CRSP, Compustat \\
\hline \multirow{2}{*}{ Tobin's Q } & MarketValueOfCommonStock + preferredStock & $24 * 25+10$ \\
\hline & BookValueOfEquity & 60 \\
\hline Size & LOG(Total Asset) & LOG(6) \\
\hline \multirow{2}{*}{ Leverage } & LongTermDebt & 9 \\
\hline & $\overline{\text { LongTermDebt }+ \text { MVofCommonStock }}$ & $9+24 * 25$ \\
\hline \multirow{2}{*}{ Coverage } & InterestExpense & 15 \\
\hline & $\overline{\text { InterestExpense + NetIncome }}$ & $\overline{15+18+14}$ \\
\hline Year & $\begin{array}{l}=1 \text { if Year }=2001 \\
=0 \text { otherwise }\end{array}$ & \\
\hline
\end{tabular}

